\title{
NANDROLONE DECANOATE IS PROOXIDANT IN THE MYOCARDIUM OF EXERCISED OR SEDENTARY RATS
}

\author{
DECANOATO DE NANDROLONA ÉPRO-OXIDANTE NO MIOCÁRDIO DE RATOS TREINADOS \\ ESEDENTÁRIOS
}

DECANOATO DE NANDROLONA ES PROOXIDANTE ENEL MIOCARDIO DERATONES ENTRENADOS
Julyara Lima Pinheiro' 1 D
(Physician)
Bernardo Porto Maia' 1 (DD
(Physician)

Anderson Bentes de Lima² (iD (Pharmacist)

Robson José de Souza Domingues² (ID (Biologist)

Fabíola Raquel Tenório Oliveira² (DD (Biomedical scientist)

Jofre Jacob da Silva Freitas ${ }^{2}$ (ID

(Biomedical scientist)

Kátia Simone Kietzer² (DD

(Physiotherapist)

1. Universidade do Estado do Pará, Medicine, Belém, Pará, Brazil.

2. Universidade do Estado do Pará, Department of Physiological and Morphological Sciences, Belém, Pará, Brazil.

\section{Correspondence:}

Katia Simone Kietzer

Av. Visconde de Souza Franco, 625,

Apto. 2102, Belém, Pará, Brazil.

66053-000. kkietzer@yahoo.com

\begin{abstract}
Introduction: Nandrolone decanoate is a synthetic testosterone analogue considered one of the most widely used anabolic androgenic steroids (AAS) among adolescents and athletes. Chronic ingestion of AAS increases the incidence of cardiovascular abnormalities in athletes, but the mechanism that causes these changes remains unknown. Objectives: The purpose of this study is to verify the possible effects of the use of anabolic androgenic steroids (AAS) on the morphology and oxidative metabolism of the heart in exercised and sedentary rats. Methods: This is a comparative prospective level II study. Twenty-four Wistar rats were distributed in groups that performed voluntary (TG) and sedentary (SG) running exercises, and used AAS: the Anabolic Training Group (ATG), and the Anabolic Sedentary Group (ASG). During the three months of the running protocol, the animals received an intramuscular injection of $5 \mathrm{mg} / \mathrm{kg}$ b.p. of AAS. After the training period, the rats were euthanized and the hearts were removed for evaluation of lipid peroxidation and antioxidant capacity, and for morphometric analysis. Results: The anabolic groups, ASG $(0.3072 \pm 0.0531)$ and ATG $(0.2732 \pm 0.0413)$, presented higher lipid peroxidation when compared to the non-anabolic groups SG $(0.1705 \pm 0.0224)$ and TG $(0.1785 \pm 0.0340)$. Conclusion: There was no change in total antioxidant capacity or in the thickness of the interventricular septum and left ventricular wall. Thus, the use of anabolic androgenic steroids did not cause morphological changes in the myocardium. However it did alter the oxidative metabolism. It was also verified that aerobic exercise had no protective effect against lipid peroxidation in the myocardium caused by the use of AAS. Level of evidence Il; Prospective comparative study.
\end{abstract}

Keywords: Exercise; Oxidative stress; Heart; Anabolic agents.

\section{RESUMO}

Introdução: O decanoato de nandrolona é um análogo sintético da testosterona, considerado um dos esteroides anabólicos androgênicos (EAA) mais utilizados entre adolescentes e atletas. Sua ingestão crônica aumenta a incidência de anormalidades cardiovasculares em atletas, porém o mecanismo que causa essas alterações ainda permanece desconhecido. Objetivos: O estudo teve como objetivo verificar os possiveis efeitos do uso de esteroides anabólicos androgênicos (EAA) na morfologia e no metabolismo oxidativo do coração de ratos treinados e sedentários. Métodos: Trata-se de um estudo prospectivo comparativo nivel II. Vinte e quatro ratos Wistar foram distribuídos em grupos que realizaram exercícios de corrida voluntária (GT) e sedentários (GS) e faziam uso dos EAA, Grupo Treinado com Anabolizante (GTA) e Grupo Sedentário com Anabolizante (GSA). Durante os três meses do protocolo de corrida, os animais receberam injeção intramuscular de $5 \mathrm{mg} / \mathrm{kg}$ p.c. de EAA. Após o período de treinamento, houve a eutanásia e remoção do coração dos ratos para avaliação da peroxidação lipídica e capacidade antioxidante, além da análise morfométrica. Resultados: Verificaram-se que os grupos anabolizantes, GSA $(0,3072 \pm 0,0531)$ e GTA $(0,2732 \pm 0,0413)$, apresentaram maior peroxidação lipídica quando comparados aos grupos não anabolizantes GS $(0,1705 \pm 0,0224)$ e GT $(0,1785 \pm 0,0340)$. Conclusões: Não houve alteração na capacidade antioxidante total, assim como não houve alteração na espessura do septo interventricular e da parede ventricular esquerda. Portanto, o uso de esteroides anabólicos androgênicos não provocou alterações morfológicas no miocárdio, contudo alterou o metabolismo oxidativo. Verificou-se também que a prática de exercício aeróbico não teve efeito protetor contra a peroxidação lipídica no miocárdio provocada pelo uso dos EAA. Nível de evidência Il; Estudo prospectivo comparativo.

Descritores: Exercício; Estresse oxidativo; Coração; Anabolizantes.

\section{RESUMEN}

Introducción: El decanoato de nandrolona es un análogo sintético de la testosterona considerado uno de los esteroides anabólicos androgénicos (EAA) más utilizados entre los adolescentes yatletas. Su ingestión crónica aumenta la incidencia de anomalías cardiovasculares en atletas, aunque el mecanismo que causa esas alteraciones sigue siendo desconocido. Objetivos: El estudio tuvo como objetivo verificar los posibles efectos del uso de esteroides anabólicos androgénicos (EAA) en la morfología y en el metabolismo oxidativo del corazón de ratones entrenados y sedentarios. Métodos: Se trata de un estudio prospectivo comparativo nivel II. Fueron distribuidos 24 ratones Wistar en grupos que realizaron ejercicios de 
carrera voluntaria (GE) y sedentarios (GS), y hacían uso de los EAA, Grupo Entrenado con Anabolizante (GEA) y Grupo Sedentario con Anabolizante (GSA). Durante los tres meses del protocolo de carrera, los animales recibieron inyección intramuscular de $5 \mathrm{mg} / \mathrm{kg}$ p.c. de EAA. Después del período de entrenamiento, hubo la eutanasia y remoción del corazón de los ratones, para evaluación de la peroxidación lipídica y capacidad antioxidante, además del análisis morfométrico. Resultados: Se verificó que los grupos anabolizantes, GSA $(0,3072 \pm 0,0531)$ y GEA $(0,2732 \pm 0,0413)$, presentaron mayor peroxidación lipídica cuando comparados a los grupos no anabolizantes $G S(0,1705 \pm 0,0224)$ y GE $(0,1785 \pm 0,0340)$. Conclusiones: No hubo alteración en la capacidad antioxidante total, así como no hubo alteración en el espesor del septo interventricular y de la pared ventricular izquierda. Por lo tanto, el uso de esteroides anabólicos androgénicos no provocó alteraciones morfológicas en el miocardio, aunque alteró el metabolismo oxidativo. Se verificó también que la práctica de ejercicio aeróbico no tuvo efecto protector contra la peroxidación lipídica en el miocardio provocada por el uso de EAA. Nivel de evidencia Il; Estudio prospectivo comparativo.

Descriptores: Ejercicio; Estrés oxidativo; Corazón; Anabolizantes.

\section{INTRODUCTION}

Nandrolone decanoate is a synthetic testosterone analogue considered one of the most widely used anabolic androgenic steroids (AAS) among adolescents and athletes. ${ }^{1}$ Androgens abuse, often called anabolic steroids, has become a worldwide problem in the last few decades. Abuse is prevalent in some countries, including Brazil. Its effects have attracted the attention of non-athletes who seek to improve the aesthetic aspect through the hypertrophic response of the muscles to the use of AAS. ${ }^{2}$ Muscle hypertrophy occurs by increasing protein synthesis, by promoting nitrogen retention, and by promoting the inhibition of protein catabolism and the stimulation of erythropoiesis. ${ }^{3}$

However, research in the last 5 decades has documented several adverse effects of AAS on different organ systems ${ }^{1}$. In the cardiac system, AAS abuse causes cardiac hypertrophy, hypertension and diastolic dysfunction. ${ }^{4}$ Chronic ingestion of AAS increases the incidence of cardiovascular abnormalities in athletes, but the mechanism that causes these changes remains unknown. The myocardium is a tissue particularly sensitive to sexual steroids, to the extent that it expresses receptors for both androgens and estrogens. ${ }^{5}$ In addition, the myocardium is characterized by high oxygen consumption, which associated with exercise response may result in increased production of reactive oxygen species (ROS) and imbalance of oxidative metabolism. ${ }^{6}$

The purposes of the study are to verify the possible adverse effects of nandrolone decanoate on the morphology and oxidative metabolism of the myocardium of rats under conditions of sedentarism and aerobic exercise and publicize the health risks that the consumption of AAS cause.

\section{METHODS}

A cross-sectional study aimed at evaluating the possible adverse effects of nandrolone decanoate on the morphology and oxidative metabolism of rats myocardiums. This is a comparative prospective study level II.

Twenty-four adult male Wistar rats (Rattus norvergicus albinus) between 90 and 120 days, weighing between 200 and 270 grams, were kept in an environment with controlled factors such as humidity, noise, temperature at $22^{\circ} \mathrm{C}$, obeying to a light / dark photo photo cycle of 12 hours, receiving water and feed ad libitum throughout the experiment.

The animals of the present research were cared for in accordance to the regulations of the Brazilian College of Animal Experimentation (COBEA) and the National Legislation for the vivisection of animals in force (Federal Law 6,638 of May $8^{\text {th }}, 1979$ ), and the research draft was approved by the Animals Care and Use Ethics Committee of the Biological Sciences and Health Center of the State University of Pará, under protocol number 14/10 SUB 1.
The animals were randomly assigned into four groups: exercising group treated with AAS (GAT, $n=6)$, sedentary group treated with AAS $(G A S, n=6)$, non-treated exercising group, $n=6)$, and non-treated sedentary group $(G S, n=6)$.

The animals of the GAT and GT groups were packed in boxes containing free access to the voluntary running wheel (Insight, Brazil) six hours a day, three times a week, for twelve weeks. Thirty minutes before the start of training, GAT and GAS animals received $5 \mathrm{mg} / \mathrm{kg}$ p.c. i.m. of Nandrolonane Decanoate in the quadriceps femoris muscle. GT and GS animals received an intramuscular dose of mineral oil $0.2 \mathrm{~mL} / \mathrm{kg}$ p.c., a medium used to solubilize AAS, in the same proportions and in the same period.

After the experimental period, the animals were sacrificed by decapitation, its hearts were removed and fragments of it were collected and immediately frozen in liquid nitrogen for further biochemical processing. For morphometry, close and excludable cardiac fragments were collected at the apex, with an angle perpendicular to the interventricular septum, in order to guarantee the posterior measurement of the thickness of the left ventricular wall and the interventricular septum.

The tissue fragments were treated according to conventional histological technique and were then fixed, dehydrated, diaphanized and included in paraffin blocks. For left ventricular morphometry and interventricular septum, histological lamellae of transverse sections of the heart were made with $5 \mu \mathrm{m}$ thick sections stained by hematoxylin-eosin $(\mathrm{HE})$. The slides were analyzed using axiovision software installed on a

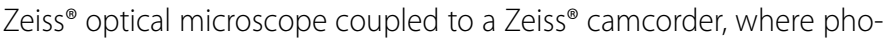
tomicrographs were obtained on 40x magnification lenses, which were projected onto the monitor. With the aid of the mouse the researcher traced a perpendicular line on the left ventricular wall and interventricular septum. The system quantified the length of the drawn line and thus determined the thicknesses. The thickness of the left ventricle and the interventricular septum of twenty sections for each animal.

To determine the lipid peroxidation it was used the modified Winterbourn et al ${ }^{7}$ for spectrophotometric analysis, in which the concentration of thiobarbituric acid reactive substances (TBARS) is evaluated. The method is based on the change in the staining of the sample when in contact with thiobarbituric acid. The colorimetric analysis used spectrophotometry at a wavelength of $532 \mathrm{~nm}$.

The anti-oxidant potential of the myocardium was determined by its equivalence to trolox, a synthetic analogue of water-soluble Vitamin E. ${ }^{8}$ It is a colorimetric technique based on the reaction between ABTS (2,2'-azinobis-3-ethylbenzothiazoline-6-sulfonic acid-diammonium) and potassium persulfate (K2S2O8), directly producing the cationic radical ABTS $\cdot+$ green / blue coloring chromophore. The addition of anti-oxidants 
to this radical reduces it again to ABTS, in the extent and time scale dependent on anti-oxidant capacity, anti-oxidant concentration and reaction time. This can be measured by spectrophotometry at $734 \mathrm{~nm}$ for a period of 5 minutes.

\section{Statistical analysis}

Regarding the nature of the variables, comparative statistical analysis of the quantitative type was applied between the results verified in each experimental group studied. For this analysis, the ANOVA test with Tukey's post-test was used through the Biostat 5.0 program. The significance level was $5 \%(p \leq 0.05)$.

\section{RESULTS}

Morphological analysis did not show a significant difference in the thickness of the left ventricle between the trained and sedentary rats. There was also no difference between the animals treated with AAS and the animals of the control group. (Table 1)

The biochemical analysis showed a significant increase in the lipid peroxidation in the myocardium of the animals that were submitted to the use of AAS when compared to those that did not use it. (Figure 1, Table 2)

When analyzing the antioxidant activity of rat myocardium, no significant difference was observed between the groups. (Table 2)

Table 1. Thickness of the left ventricle ( $\mu \mathrm{m})$ and interventricular septum $(\mu \mathrm{m})$ of trained and sedentary Wistar rats treated with androgenic anabolic steroid Nandrolone decanoate.

\begin{tabular}{c|c|c}
\hline Groups & $\begin{array}{c}\text { Left ventricle } \\
\text { thickness }\end{array}$ & $\begin{array}{c}\text { Interventricular septal } \\
\text { thickness }\end{array}$ \\
\hline GS & $1781.1 \pm 634.4$ & $1468.4 \pm 169.8$ \\
\hline GT & $2313.5 \pm 798.1$ & $2077.6 \pm 744.2$ \\
\hline GAS & $2436.8 \pm 512.6$ & $2011.3 \pm 305.4$ \\
\hline GAT & $2474.2 \pm 402.3$ & $1955.6 \pm 117.4$ \\
\hline
\end{tabular}

Research Protocol; Anova-Tukey; $n=6$ per group; $p \geq 0,05$.

Table 2. Concentration of thiobarbituric acid reactive substances (uMol / mg protein) and total antioxidant capacity equivalent to the Trolox of the myocardium of trained and sedentary Wistar rats treated with nandrolone decanoate.

\begin{tabular}{c|c|c}
\hline Groups & TBARS & TEAC \\
\hline GS & $0.3533 \pm 0.1260$ & $0.1705 \pm 0.0224$ \\
\hline GT & $0.2851 \pm 0.0891$ & $0.1785 \pm 0.0340$ \\
\hline GAS & $0.3932 \pm 0.1018^{*}$ & $0.3072 \pm 0.0531$ \\
\hline GAT & $0.3954 \pm 0.0938^{*}$ & $0.2732 \pm 0.0413$ \\
\hline
\end{tabular}

Research Protocol; Anova-Tukey; TBARS - * $p \leq 0.01 ;$ TEAC - $p \geq 0.05$

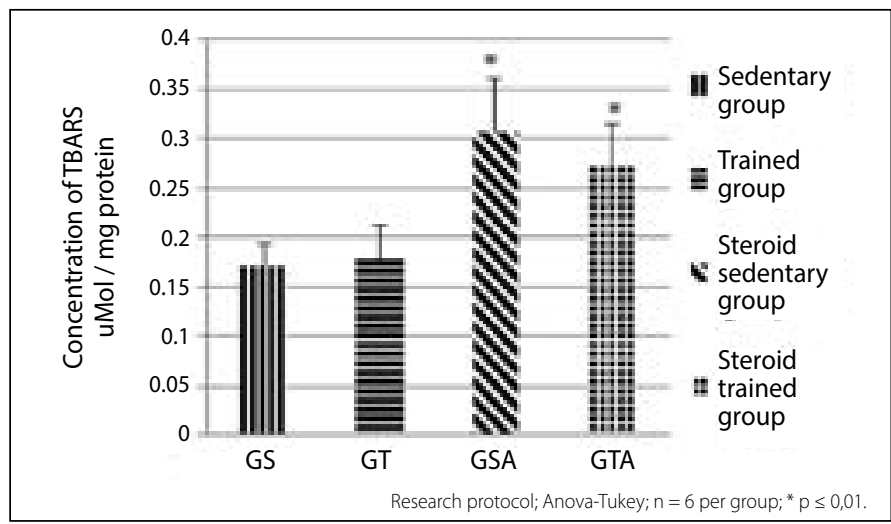

Figure 1. Concentration of thiobarbituric acid reactive substances in the myocardium of trained and sedentary Wistar rats treated with Nandrolone Decanoate.

\section{DISCUSSION}

The present study verified that the use of AAS promotes changes in the oxidative metabolism in the myocardium of sedentary or exercised rats, but that this effect does not translate into morphological alterations.

Current literature reports the use of different doses of AAS, with low doses being used more frequently for long periods of time. ${ }^{8}$ This study used the preferred dosage between human ASA users to promote muscular hypertrophy during the training period. However, both high and low doses of nandrolone increase lipid peroxidation in the heart muscle. ${ }^{9}$

The present study showed that the regular practice of voluntary aerobic exercise in animals that did not use AAS did not cause alteration in the oxidative metabolism in the myocardium of the trained animals. This fact may be related to the intensity and regularity of the exercise practiced by the animals, thus establishing the difference in the oxidative response.

Intense exercise increases oxygen consumption and can produce imbalance between ROS and antioxidants, inducing oxidative stress as a result of increased production of ROS. Increased oxidative metabolism elevates the escape of electrons from the mitochondrial transport system and disrupts pro-oxidant and antioxidant intracellular homeostasis, leading to redox state of damage and imbalance. ${ }^{6}$

Thus, it is known that modulation of redox balance is highly dependent on the level of physical activity. Acute or exhaustive exercises cause oxidative stress due to the inability of the organism to fight against the flood of ROS produced. ${ }^{10}$

The non-exhaustive exercise, in turn, has as one of the main benefits, the induction of mild oxidative stress, which results in the stimulation of the expression of antioxidant enzymes. This is mediated by the activation of signaling pathways sensitive to the redox state. ${ }^{6}$ It is believed that moderate exposure to ROS is necessary to induce the adaptive response of the body, such as the activation of antioxidant defense mechanisms. ${ }^{11}$

The regularity of the exercise plays a crucial role, as it promotes a compensatory mechanism to oxidative stress, resulting in overcompensation against the increase of ROS production, by increasing the antioxidant capacity. ${ }^{11}$ Regular exercise stimulates adaptive responses and strengthens the defense system of endogenous antioxidants to combat ROS excess, thereby maintaining redox muscle balance. ${ }^{10}$

In addition, it appears that the oxidative effects related to exercise are systemic. Intense acute exercise increases ROS production and inflammation, while regular training induces antioxidant and anti-inflammatory increase in the liver of exercised rats. ${ }^{12}$ Skeletal muscle, liver and brain have very different metabolic rates and functions during exercise, but the adaptive response is very similar, with increased enzymatic activity, lower oxidative damage and greater resistance to oxidative stress, due to changes in redox homeostasis. ${ }^{11}$ The heart is characterized by one of the highest rates of oxygen consumption at rest between all the organs of the body. This consumption is even higher in response to exercise and may result in increased production of reactive oxygen species and impairment of the oxidant-antioxidant balance. However, increased ROS production is detectable in the rat myocardium during acute exercise. ${ }^{13}$ The effect of exercise on the myocardium and vascular system is known to be dependent on the frequency, intensity, and duration of exercise. ${ }^{14}$

Electronically induced tachycardia, which mimics the cardiac effects of exercise, sharply decreases the activities of antioxidant enzymes in the left ventricle of the rat's heart. ${ }^{15}$ However, reports on the effects of physical training on enzymatic and non-enzymatic antioxidant cardiac systems are inconclusive. ${ }^{16}$ 
In the short-term non-compulsory exercise performed on running wheel, there was no difference in antioxidant capacity and the increase in exercise duration also did not bring about changes in antioxidant capacity. ${ }^{17}$ However, Naderi et al. ${ }^{18}$ found that voluntary exercise decreases oxidative stress and lipid peroxidation in the heart and blood of diabetic rats. The difference between exercise protocols may explain the discrepant results. It is difficult to compare the results of the voluntary race with other modalities since the duration and intensities of these types of exercises are typically much larger than the voluntary running of the wheel and are generally performed in much shorter periods of time.

Thus, the exercise performed voluntarily by the animals of the present study, promoted the necessary adaptations, without generating damage in the oxidative metabolism in these animals hearts.

However, in both groups in which the animals were treated with AAS, it was observed that the concentration of thiobarbituric acid reactive substances increased significantly in the myocardium and did not promote alteration of the total antioxidant capacity.

The AAS abuse is associated with cardiovascular disorders and oxidative stress is one of the most potent inducers of endothelial dysfunction and cardiovascular disease. Prolonged administration of steroids may cause dysfunction of the mitochondrial respiratory chain complex and mono-oxygenase leading to increased generation of ROS..$^{19}$ In the work of Germanakis et al. ${ }^{20}$ there was a decrease in antioxidant enzymes such as catalase and increase in thiobarbituric acid reactive substances. For Chaves and Fortunato et al. ${ }^{21}$ the use of AAS abolished the exercise-induced protection found that there was a decrease in cardiac cardioprotection through the blockade of the antioxidant enzymes superoxide dismutase and glutathione peroxidase in the anabolic groups, and in the trained group without anabolic agent, this fact did not occur. Similar results were found in Tanno et al. ${ }^{22}$ and Sadowska-Krepa et al. ${ }^{16}$

Thus, we verified in the present study that the use of AAS increased lipid peroxidation without increasing the total antioxidant activity, and that the exercise did not promote any type of protection on the heart from the oxidative point of view. In the present study, there was no difference in the thickness of the left ventricular wall or the interventricular septum. Since the use of AAS is more related to modalities involving power and muscular strength, the effects of its association with aerobic training on cardiac hypertrophy are not much studied. ${ }^{23}$

Yeater et al. ${ }^{23}$ showed that there was no increase in the thickness of the left ventricular wall and the interventricular septum in bodybuilders exercising AAS users. The aerobic training of rats on treadmills associated with AAS treatment did not show an increase in heart weight. ${ }^{24}$ Soares et al. ${ }^{25}$ Do Carmo et al. ${ }^{26}$ and Koike ${ }^{27}$ reported in their studies weight gain and left ventricular thickness of the hearts of rats which practiced swimming associated with the use of AAS. In the protocol developed by Germanakis et al. ${ }^{20}$ only AAS was used in adult rabbits, without the practice of physical exercise. The analysis of the heart size performed by echocardiogram demonstrated hypertrophy of the left ventricular wall and increased ejection fraction of the rabbits anabolic heart. Bissoli et al. ${ }^{28}$ treated rats with supraphysiological doses of nandronola decanoate and observed left and right ventricular hypertrophy.

In the studies cited in which the animals practiced aerobic exercise, it was verified that the type of training and the intensity may have influenced the hypertrophic process, since the exercise modality and the weekly training frequency differ from the present study, although these studies used the same type of AAS. Although many studies show the protective effects of exercise, the mechanisms associated with this phenomenon remain controversial, suggesting that the animal used, type and volume of exercise would influence the level of protection and the activated cardioprotective mechanisms. ${ }^{29}$

\section{CONCLUSION}

Our results showed that the consumption of AAS decreases nandrolone decanoate ROS production in the myocardium of rats observed through lipid peroxidation by-products.

We did not observe alterations in the antioxidant activity, probably by the use of a technique that evaluates the antioxidant set, in relation to lipid peroxidation.

The results related to oxidative metabolism also allowed us to conclude that the oxidative effect of AAS in the myocardium of rats is similar in both trained and sedentary rats, showing that aerobic exercise had no cardioprotective effect against the use of AAS.

The results of the morphological analysis showed that the AAS at the dosage, frequency and period of use, associated or not with aerobic physical exercise does not promote significant changes in the thickness of the left ventricle and the interventricular septum of the heart.

Finally, it can be verified that the AAS nanoanate decanoate, alone or in combination with physical exercise, is pro-oxidant in the myocardium of rats.

\section{ACKNOWLEDGMENTS}

This research was supported by grants from CNPq, CAPES and Laboratory of Morphophysiology Applied to Health, CCBS-UEPA, UEPA.

The authors are grateful for the technical assistance of Marcio Amorim of the Laboratory of Morphophysiology Applied to Health, CCBS-UEPA, UEPA.

All authors declare no potential conflict of interest related to this article

AUTHORS' CONTRIBUTIONS: Each author made significant individual contributions to this manuscript. JLP, BPM and ABL performed the research, analyzed the data, and prepared the manuscript; RJSD analyzed the histologic slides, performed the morphological analysis, and participated in the discussion of the work; FRTO assisted in the data collection, tabulation and interpretation, and helped in the statistical analysis; JJSF provided guidance for the study, analyzed the histologic slides and performed the morphological analysis; KSK designed the study, analyzed the data, and prepared and reviewed the manuscript.

\section{REFERENCES}

1. Barone R, Pitruzzella A, Marino Gammazza A, Rappa F, Salerno M, Barone F, et al. Nandrolone decanoate interferes with testosterone biosynthesis altering blood-testis barrier components. J Cell Mol Med. 2017; 21(8):1636-47.

2. Kanayama G, Pope HG Jr. History and epidemiology of anabolic androgens in athletes and non-athletes. Mol Cell Endocrinol. 2018;464:4-13.

3. Radak Z, Zhao Z, Koltai E, Ohno H, Atalay M. Oxygen Consumption and Usage During Physical Exercise: The Balance Between Oxidative Stress and ROS-Dependent Adaptive Signaling. Antioxid Redox Signal. 2013;18(10):1208-46

4. Nikolic T, Zivkovic V, Jevdjevic $M$, Djuric $M$, Jeremic $N$, Djuric $D$, et al. The effects of chronic administration of nandrolone decanoate on redox status in exercised rats. Mol Cell Biochem. 2016;411(1-2):95-105.
5. Marsh JD, Lehmann MH, Ritchie RH, Gwathmey JK, Green GE, Schiebinger RJ. Androgen receptors mediate hypertrophy in cardiac myocytes. Circulation. 1998;98(3):256-61.

6. Bejma J, Ramires P, Ji LL. Free radical generation and oxidative stress with ageing and exercise: differential effects in the myocardium and liver. Acta Physiol Scand. 2000, 169(4):343-51.

7. Winterbourn CC, Gutteridge JM, Halliwell B. Doxorubicin-dependent lipid peroxidation at low partial pressures of O2. J Free Radic Biol Med. 1985;1(1):43-49.

8. Re R, Pellegrini N, Proteggente A, Pannala A, Yang M, Rice-Evans C. Antioxidant activity applying an improved ABTS radical cation decolorization assay. Free Radic Biol Med. 1999;26(9-10):1231-7.

9. Bissoli NS, Medeiros AR, Santos MC, et al. Long-term treatment with supraphysiological doses of nandrolone decanoate reduces the sensitivity of Bezold-Jarisch reflex control of heart rate and blood pressure. Pharmacol Res. 2009;59(6):379-84. 
10. Nikolic TR, Zivkovic VI, Srejovic IM, Radovanovic DS, Jeremic NS, Jevdjevic MD, et al. Acute effects of nandrolone decanoate on cardiodynamic parameters in isolated rat heart. Can J Physiol Pharmacol. 2016;94(10):1048-57.

11. Debevec T, Millet GP, Pialoux V. Hypoxia-Induced Oxidative Stress Modulation with Physical Activity Front Physiol. 2017;8:84

12. Radak Z, Ishihara K, Tekus E, Varga C, Posa A, Balogh I, et al. Exercise, oxidants, and antioxidants change the shape of the bell-shaped hormesis curve. Redox Biol. 2017;12:285-90.

13. Pillon Barcelos R, Freire Royes LF, Gonzalez-Gallego J, Bresciani G. Oxidative stress and inflammation: liver responses and adaptations to acute and regular exercise. Free Radic Res. 2017;51(2):222-36.

14. Duncker DJ, Bache RJ. Regulation of Coronary Blood Flow During Exercise. Physiol Rev. 2008;88(3):1009-86.

15. Bejma J, Ramires P, Ji LL. Free radical generation and oxidative stress with ageing and exercise: Differential effects in the myocardium and liver. Acta Physiol Scand. 2000;169(4):343-51.

16. Sadowska-Krępa E, Kłapcińska B, Jagsz S, Sobczak A, Chrapusta SJ, Chalimoniuk M, et al. High-dose testosterone propionate treatment reverses the effects of endurance training on myocardial antioxidant defenses in adolescent male rats. Cardiovasc Toxicol. 2011;11(2):118-27.

17. Selman C, McLaren JS, Collins AR, Duthie GG, Speakman JR. Antioxidant enzyme activities, lipid peroxidation, and DNA oxidative damage: the effects of short-term voluntary wheel running. Arch Biochem Biophys. 2002;401(2):255-61.

18. Naderi R, Mohaddes G, Mohammadi M, Ghaznavi R, Ghyasi R, Vatankhah AM. Voluntary exercise protects heart from oxidative stress in diabetic rats. Adv Pharm Bull. 2015;5(2):231-6.

19. Tofighi A, Shirpoor M, Ansari MH, Shirpoor A, Zerehpoosh M. The effect of nandrolone treatment with and without enforced swimming on histological and biochemical changes in the heart and coronary artery of male rats. Anatol J Cardiol. 2017;17(3):176-83.

20. Germanakis I, Tsarouhas K, Fragkiadaki P, Tsitsimpikou C, Goutzourelas N, Champsas MC, et al. Oxidative stress and myocardial dysfunction in young rabbits after short term anabolic steroids administration. Food Chem Toxicol. 2013;61:101-5.
21. Chaves EA, Fortunato RS, Carvalho DP, Nascimento JH, Oliveira MF. Exercise-induced cardioprotection is impaired by anabolic steroid treatment through a redox-dependent mechanism. J Steroid Biochem Mol Biol. 2013;138:267-72. doi:10.1016/j.jsbmb.2013.06.006.

22. Tanno AP, das Neves VJ, Rosa KT, Cunha TS, Giordano FC, Calil CM, et al. Nandrolone and resistance training induce heart remodeling: role of fetal genes and implications for cardiac pathophysiology. Life Sci. 2011;89(17-18):631-7.

23. Yeater R, Reed C, Ullrich I, Morise A, Borsch M. Resistance trained athletes using or not using anabolic steroids compared to runners: effects on cardiorespiratory variables, body composition, and plasma lipids. Br J Sports Med. 1996;30(1):11-14

24. Pereira-Junior PP, Chaves EA, Costa e Sousa RH, Masuda MO, de Carvalho AC, Nascimento JH. Cardiac autonomic dysfunction in rats chronically treated with anabolic steroid. Eur J Appl Physiol. 2006;96(5):487-494

25. Soares MC, Abreu IC de, Assenço F, Borges MO. Decanoato de nandrolona aumenta a parede ventricular esquerda, mas atenua o aumento da cavidade provocado pelo treinamento de natação em ratos. Rev Bras Med Esporte. 2011;17(6):420-4.

26. Do Carmo EC, Fernandes T, Koike D, Da Silva ND Jr, Mattos KC, Rosa KT, et al. Anabolic Steroid Associated to Physical Training Induces Deleterious Cardiac Effects. Med Sci Sport Exerc. 2011;43(10):1836-48.

27. Koike DC. Efeitos do treinamento físico no balanço autonômico e parâmetros cardiovasculares de ratos submetidos ao uso de esteróides anabólicos. [Dissertação de mestrado] - Programa de Pós-Graduação em Educação Física. São Paulo: Universidade São Judas Tadeu. 2009. [access in 2017 July 19]. Available in: https://www.usjt.br/biblioteca/mono_disser/mono_diss/106.pdf.

28. Bissoli NS, Medeiros AR, Santos MC, Busato VC, Jarske RD, Abreu GR, et al. Long-term treatment with supraphysiological doses of nandrolone decanoate reduces the sensitivity of Bezold-Jarisch reflex control of heart rate and blood pressure. Pharmacol Res. 2009; 59(6):379-84.

29. Williams CA. The effect of oxidative stress during exercise in the horse. J Anim Sci. 2016;94(10):4067-75 